\title{
MOHOKEA CALDERA
}

\author{
BY C. H. HITCHCOCK
}

(Presented by title before the Society December 29, 1905)

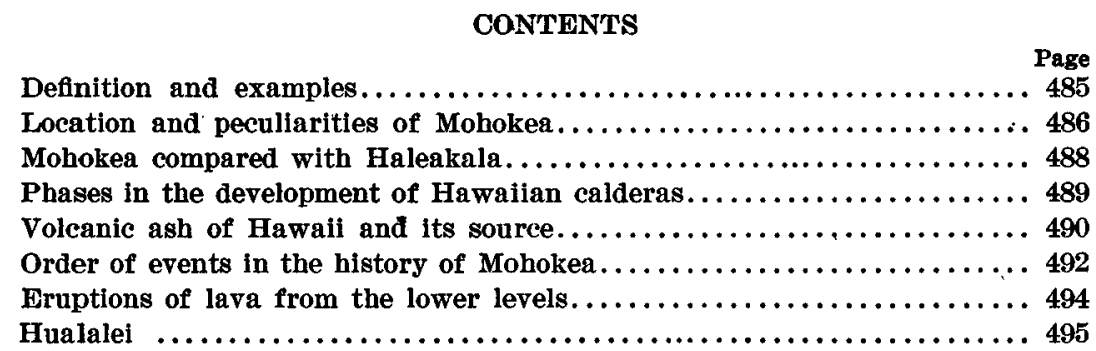

\section{Definition and ExaMPLES}

At the New York meeting* of the Society I gave some account of a singular depression on the southwest slope of Mauna Loa, calling it a caldera. My information concerning it came primarily from descriptions of the topography given by Mr J. S. Emerson, of the Hawaiian Trigonometrical Survey, which form the basis of the official map of Hawaii published in 1901. Mr Emerson had read a paper on the subject before the Social Science Association of Honolulu in October, 1895, which was published in the American Journal of Science in December, 1902, under the title of "Some characteristics of Kau." During the past summer (1905) I have visited the locality, and now proceed to describe the ascertained facts and to draw certain conclusions therefrom.

A caldera is conceived by Captain C. E. Dutton, who proposed the name, to be an immense depression "formed by the dropping of the mountain crust which once covered a reservoir of lava." The pits of

- Bull. Geol. Soc. Am., vol. 14, p. 8. 
Mokuaweoweo and Kilauea on Hawaii, Haleakala on Maui, and Crater lake in Oregon are cited as examples.

\section{Location and Peculiarities of Mohokea}

The Mohokea depression is situated in Kau, in the southwestern part of the island of Hawaii, to the north of the harbor of Honuapo, which at present is the end of the sea voyage for those who skirt the leeward side of the great island on the way from Honolulu to Kilauea. There is a line of stages from Honuapo to the volcano, rising gradually for a distance of 30 miles to the altitude of 4,040 feet. Hilea, about 4 miles from the seaport, is the best point from which to traverse the depression. It is the residence of the head overseer of the sugar plantation, who very kindly accompanied me to the principal points of interest in the caldera. From the house, situated upon lava, the road ascends a steep hill covered by volcanic ashes to about 1,200 feet altitude, and thence another thousand feet to Makawao, where the soil seems to have originated from rock decomposition. This hill is on the southeast side of Kaiholena, the highest elevation in the district.

Mauna Loa is an elongated dome 13,650 feet in height, sloping gradually to the sea or to an intersection with an adjacent volcano. On the northwest side, next to Hualalei, the base is 4,500 feet; on the northeast side, next to the extinct Mauna Kea, at the sheep ranch Humuula, the col is 6,600 feet; on the southeast side, next to Kilauea, the base is about 3,800 feet. The slopes to the sea at Hilo and South cape are gradual for distances of 30 miles. The mass of Kilauea is often regarded as being on the flank of Mauna Loa, because the discharges from the latter cover up much of the former. Kilauea is as well defined a caldera, with its own periods of eruption, as Mokuaweoweo. The locations of the eruptions from Kilauea range from Nanawili, in Puna, on the east, to Punuluu on the west, which is on the seashore only 3 miles from Hilea. A very conspicuous fault extends 20 miles long from Kohaualea westerly to near the flow of 1823. The land makai (shoreward) of this fault has dropped down 1,100 feet. A somewhat similar but more irregular escarpment may be traced from near Kapapala to Waiohinu, 17 or 18 miles in length, but is on the south slope of the mass of Mauna Loa. The caldera of Mohokea has this escarpment for its southern boundary. It is an elliptical depression, 6 miles long northwest and southeast, and 5 miles wide northeast and southwest, but truncated by the escarpment named. It has been hollowed out from the basaltic sheets of Mauna Loa. The total area is about 30 square miles. 


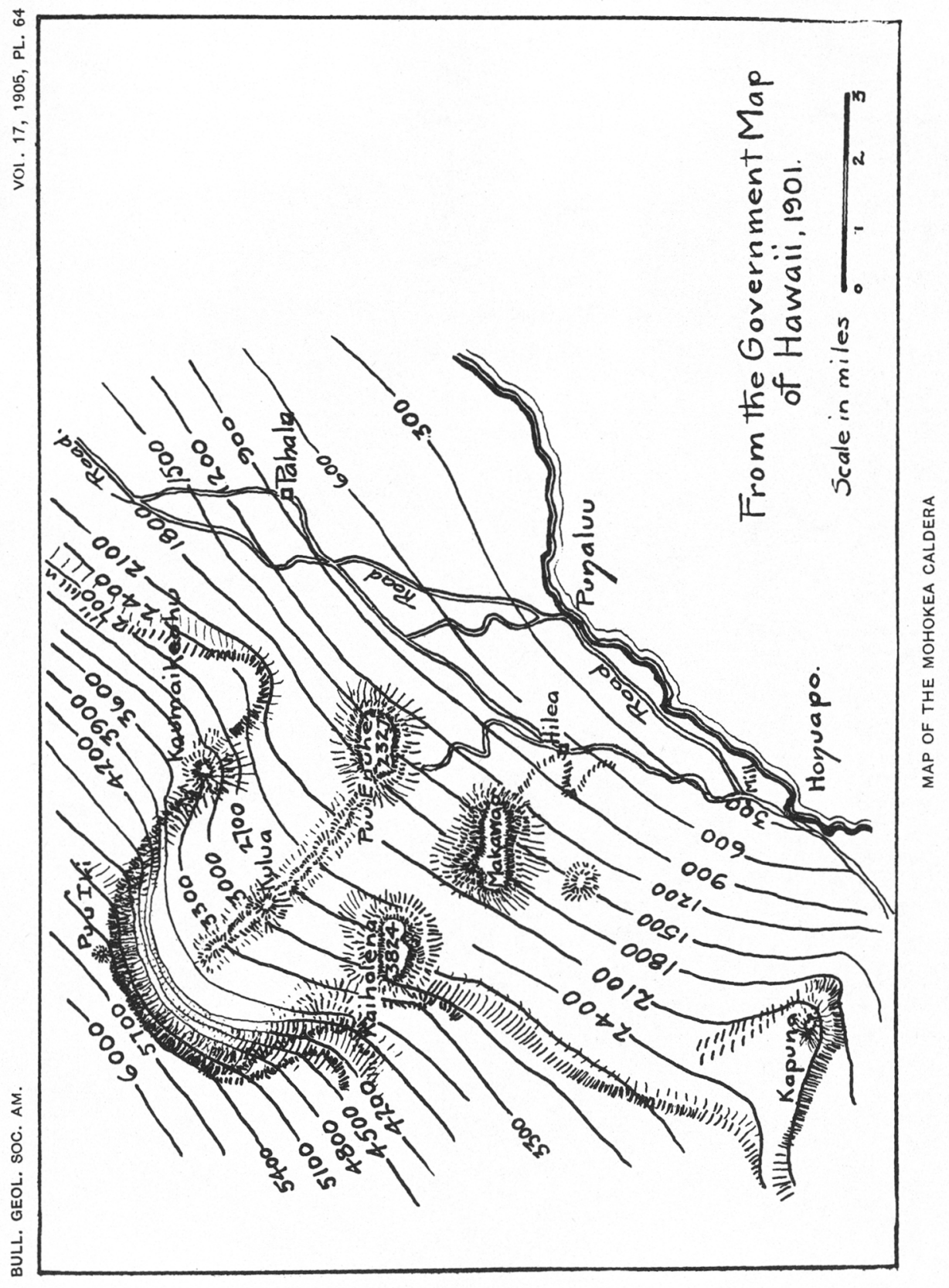


Mohokea differs from the other calderas in three respects:

1. It is not inclosed on all sides, so as to be properly a pit. It is open on the makai side.

2. There have been several flows of lava from it on the open side. (a) From the broadest part, between Puu Enuhe and Makawao. It is of aa, and has flowed down to the sea between Punuluu and an older similar stream toward Honuapu. It is evidently comparatively recent, though not recognizable in the legends of the oldest inhabitant. It can not have been active less than two centuries ago. (b) A small aa flow starts from the cliff on the west side of the gulch flanking Makawao on the west. It does not reach quite to the stage road at Hilea. It is very chrysolitic and has issued from under the later pahoehoe which overlies the yellow ash in the immediate neighborhood. (c) Another an stream, still farther west, is about one mile wide where it crosses the road. It issued from the cliff on the west side of Makawao, but from between two spurs of the older pahoehoe. Following this the road traverses a mile of pahoehoe before coming to $(d)$, the last aa flow, one and a half miles wide, reaching to a short distance east of the sugar mill at Honuapo. The older aa streams are covered by large kukui trees (Cordia), with their characteristic lighter yellow green color, rendering them conspicuous.

3. The greatest peculiarity in Mohokea consists in the presence of two parallel lines of faulted blocks running northwest from the southeastern edge. The one on the east is known at Puu Enuhe, rising precipitously along the edge of the cliff to the height of 2,327 feet. This is the most conspicuous of all the blocks and is the one most like the buttes of the Rocky Mountain region. The ridge behind the outer block falls away gradually for nearly 3 miles, and then rises again abiuptly to Kulua, only to fall away again as at first, and reaches nearly to the innermost wall of the caldera. Viewed from a distance on either flank, the ridge resembles a huge worm with a great head and a swelling near the caudal extremity. This resemblance caught the attention of the early Hawaiians, who recite an interesting legend respecting its origin.*

To the west of Puu Enuhe lies a valley one and a half miles wide. It is inhabited by Hawaiians who exhibit characteristic features of the life of the olden time. They are highlanders as contrasted with lowlanders. On the west side the valley is flanked by stupendous blocks, of

- Very long ago there lived here a charming maiden with three brothers. Among her visitors was one possessing great attractions, who always came after dark and left before daylight. The brothers found that their sister loved this visitor, and they had suspicions that he was more than mortal. In order to satisfy themselves they selzed hold of him just as he was leaving, and compelled him to remain with them. As soon as daylight came he was changed into this enormous worm. He was evidently one of those delties who could not retain the human form in the presence of mortals after daylight. 
which the first is Makawao, estimated to exceed 3,500 feet in height. It is hardly separated from Pakua, which is not represented on figure , a map of this district copied from the government map of Hawaii, 1901. A broader notch separates Pakua from Kaiholena, 3,824 feet high. There are five blocks in this row, into the last of which a tunnel has been driven two hundred feet in quest of water for irrigation. The east side of this line of blocks is quite precipitous, representing the place of a fault. Both the lines of blocks have been elevated, as indicated on the map, their altitudes being greater than that of the adjacent territory. The lowland between the elevated blocks and the east side rises gradually to the steep wall behind, toward Puu iki. The land is not cultivated for most of the distance, and is covered by the original forest of tree-ferns, ohias, and other hardwood trees, similar to those seen on the volcano road in Olaa. On the west side of Pakua may be seen the bed of a mountain torrent, usually dry, but often too full of water to be safely forded. This skirts the eastern border of another lowland area like those already mentioned, save that it is cultivated and used for pasturage. It is over a mile wide and has a floor of fresh looking pahoehoe, sloping gradually to the edge of the frontal escarpment, about 1,200 feet high. Eruptions of aa have proceeded from this edge along the whole width of the caldera.

The Enuke and Kaiholena ridges are higher than the slopes of the Mauna Loa basalt opposite them, of which it is supposed they once formed a part. Hence the lowland depressions can not be regarded as the results of canyon erosion; they probably were depressed, while the blocks were elevated. Following the definition of the caldera, it may be said that portions of the mountain crust were dropped, while other sections were elevated. Its development was arrested. The making of the caldera was incomplete. Possibly the great size of Mohokea, comprising 30 square miles, while Haleakala is only 19, may have militated against the thorough fusing of the entire bulk.

\section{MOHOKEA COMPARED WITH HALEAKALA}

For a further understanding of a caldera, reference should be made to Haleakala on Maui. This pit has an area of 19 square miles and the shape of an elbow. It is 4 miles across from the outer to the inner angle. The greatest length, toward (east) Kaupo, is 7.48 miles. Toward Koolau (north) the distance is 6 miles. The greatest width is 2.37 miles. The depression is 2,000 feet deep, with many small craters inside-up to 760 feet in altitude-so it is a true caldera. The north arm is called Koolau gap; the east arm is called Kaupo gap. There is a grad- 







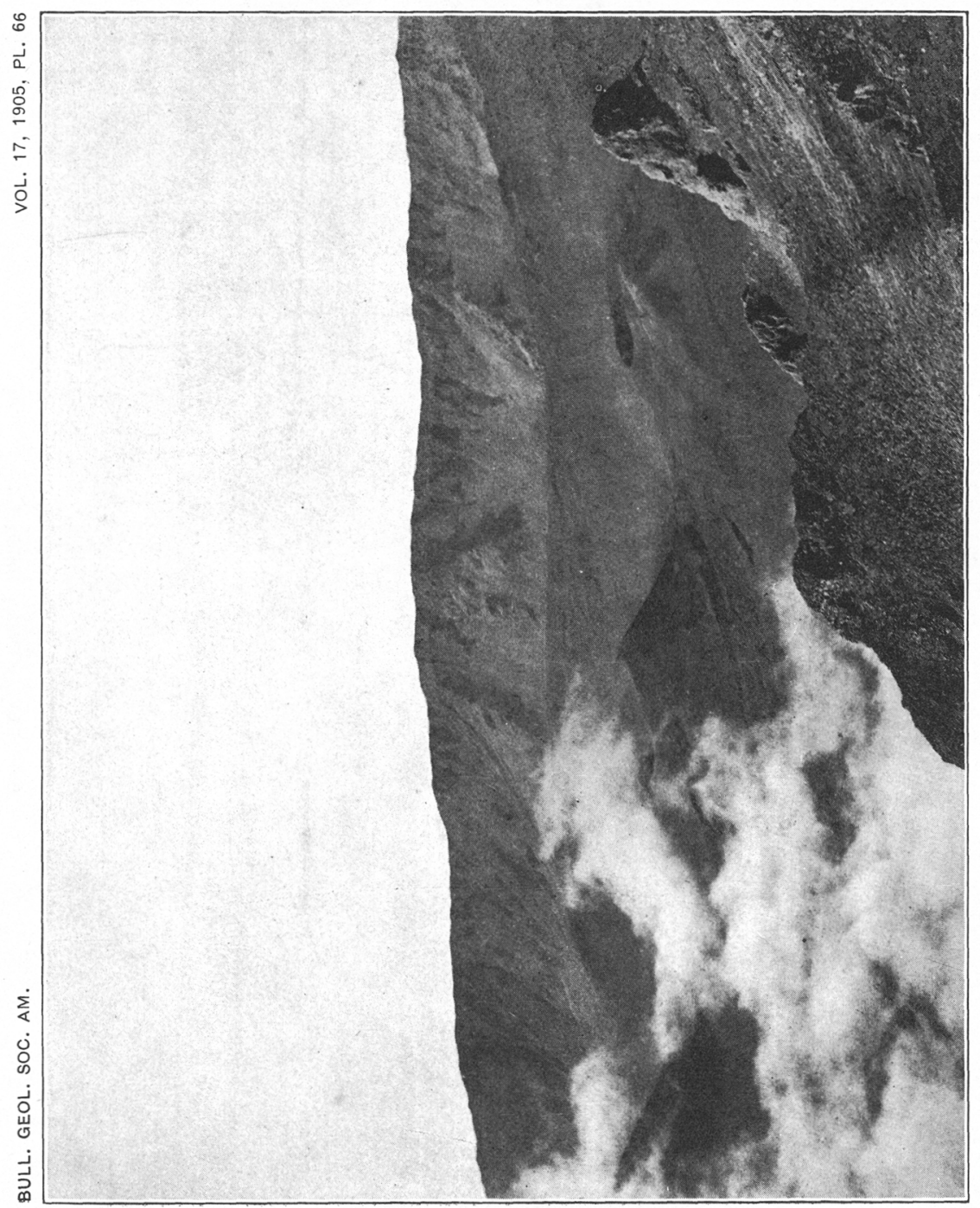

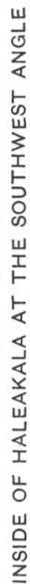


ual descent from the axis connecting the outer to the inner angles of the elbow in both directions. Where the outermost edges of the two arms are reached there is a more rapid descent, commencing with 6,500 feet at Koolau and 7,600 feet at the Kaupo gap.

The similarity between the Mohokea and Haleakala calderas consists in the presence of steep escarpments at the lower edges of the floor, and both are unlike the typical examples (Kilauea), in that they are open on one side, not encircled by a cliff. Haleakala could be conceived of as consisting of two smaller calderas united along the axis of the elbow; or it might be imagined as formed by the splitting of the mountain and a separation of the two parts, the space between being filled by later discharges.

The gaps are each continued in broad valleys to the sea. Koolan merges into the Keanae valley, reaching the sea at the village of that name, 9 or 10 miles long. This valley is now crossed transversely by an aqueduct fully 1,200 feet above the sea, carrying water for irrigation purposes to the sugar plantations of central Maui. The Kaupo gap extends to the sea in a similar manner, taking its name from the locality. These two streams of lava are larger than any now known elsewhere in the archipelago. If the lava should accumulate enormously in Kilauea, and one stream flow south to Punaluu and the other break through the barrier to the edge of Puna and thence to the sea, the topography of the caldera and its outflows would be very suggestive of Haleakala.

Two views of Haleakala are presented. Plate 65 is a restoration-an attempt to show the appearance of the caldera as if one were situated in a balloon a thousand feet above the highest point. It is reduced from a painting by E. Bailey, based upon W. D. Alexander's early map. Plate 66 is a photograph of the south wall of Kaupo, with views of some of the smaller craters inside the pit.

\section{Phases in the Development of Hawaitan Calderas}

It is easy to speculate on the relations of the several Hawaiian calderas.

At first there is a simple crater discharging lava from the summit of a dome.

Secondly, the lava is not produced in sufficient quantity to flow over the margin ; the opening is sealed, and then the outermost crust breaks up. The crust is too vast to be absorbed; blocks of it will be elevated; other sections will be absorbed, and the outer wall on the makai side may give way. There will be discharges on the lower side. This may be the Mohokea stage. 
Thirdly, all the segments of the crust fall into the reservoir beneath; vertical walls encircle a pit. This is the stage of Kilanea and Mokuaweoweo.

Fourthly, the caldera with encircling walls is formed, but the lower walls give way. Great rivers of lava flow to the sea. As the fires die down several small craters are developed on the principal floor. This is Haleakala.

Fifthly, the eruptions of the smaller craters like Halemaumau multiply and the whole pit is filled. The caldera is smothered, the smaller craters continue to be developed until the internal reservoir is exhausted. This is the Mauna Kea stage.

I could count twenty-four craters of small size visible from its summit, and the government map delineates between 75 and 80 of these cinder cones above the contour of 6,500 feet. Most of them represent the latest stages of the volcanic life of Mauna Kea and not improbably the filling of a now concealed caldera.

\section{Voldanic Ash of Hawail and its Source}

The district of Kau between Puna and Kona is proverbially dusty. The floor is of modern lava, covered over an area of 300 square miles with a light yellowish dust. Mountain torrents have washed away some of it, revealing basalts just beginning to disintegrate; that which remains is very loose, easily moved by wind or water. In the older days the natives enjoyed jumping from a high bank into the dust, just as they might leap from a bluff into the water. Of course this material is badly cut down by teams along the roads. It is utilized for the growth of sugarcane everywhere that plantations exist on the west side of Kilauea. These soils are free from rocks and are very deep, so that a crowbar or cane may be readily thrust down its whole length, just as would be true of large piles of wood ashes in a dry country. Neither is there anything adhesive in this dust when wet. No paxt of it adheres to one's shoes when walking over it in time of rain.

These soils suffer badly from drought. Extensive fields will be parched and clouds of dust will be very annoying, even imparting a reddish yellow tint to the sky. When the rain comes in torrents much damage will be done to the land by the cutting of trenches and the transportation of earth. The dry and wet periods are registered in the varied and irregular length and diameter of the joints of the sugarcane stalks. In the season of drought much pains are taken to prevent the starting of fire in the grass, as it spreads long distances beneath the surface, be- 
cause the spongy nature of this ash will allow the access of air to support the combustion.

It is often dangerous to traverse the forests above the plantations on horseback, because the animals unexpectedly plunge into unseen deep holes and break their legs. Surveyors find it impracticable to carry supplies to their workmen by direct routes over these soils and necessarily make wide detours.

In traveling from Kilauea southwesterly through Kau this ash first appears in small isolated areas 4 miles from the volcano, and then increases in amount and importance, and is more noticeable about the "Halfway House." Between this and Pahala certain piles of it, as at the level of 1,800 feet, resemble terraces. It is the material supporting the Pahala sugar plantations. It has been covered at various places in Kau by flows of pahoehoe. An isolated hill of this sort near the tramway a mile or more northeast from Punaluu harbor is conspicuous. As a rule, the lands near the sealevel have either lost this ash by rain erosion or it is covered by the later lava flows. Most of the peaks in the Mohokea area are capped by the ash, though it is recognized most abundantly near the southeast margin.

The promontory called Kahuku point, South Cape, and Ka Lae is likewise covered by this ash, and has attained the thickness of 10 feet, separated into two parts by a thin seam of earth. The late eruptions of 1868 and 1887 destroyed the continuity of this deposit between Kahuku and Kona.

Mr Emerson has discussed the problem of the source of the aerial eruption, and the writer has referred to the same question in a paper on the volcanic phenomena in Hawaii.*

King Umi's road is referred to as giving evidence of the presence of those ashes for three and a half centuries. He occupied a tract of land between Mauna Loa and Hualalei, where some of the edifices constructed by him were figured by Admiral Wilkes and are still to be seen. The road ran north and south, parallel to the shore of Kona, 7 or 8 miles distant, to a natural amphitheater on the southern slope of Puu o Keokeo, where immense crowds of Hawaiians gathered to witness the cock fights. The pens still stand as they were in Umi's day. 'The road over this ash is said to be only two or three feet wide. If a mule traversing this path deviated but a few feet on either side he would sink down to his girth and flounder helplessly. If a shower of pumice or lapilli had fallen since the days of Umi, the road and the pens would have been swept away or covered up. Hence we must regard the ash deposit as the latest formation of the neighborhood, though still several centuries old.

* Bull. Geol. Soc. Am., vol. 12, p. 83. 
Mr Emerson's final conclusion is that we must seek for the source of the ash in the district where it abounds. Considering the shape of our supposed caldera, he thinks the ashes must have proceeded from some part of it. This was the "source of the stupendous explosions or series of explosions which has rescued Kau from being a waste of unproductive rock and transformed it to so large an extent into a land of pastures and plantations."

I have already treated of this question in the paper already cited, looking to Mokuaweoweo as the probable source of this and other localities of ash on Hawaii. What is conceived to be the same duplex deposit is recognized at Puakala on the south flank of Mauna Kea, at Hilo, all through Olaa, as well as in Kau and Kona. I have the past year discovered the same deposit on the north side of Mokuaweoweo a dozen miles west of Humuula sheep station, so that now the great crater has been proved to be encircled by this light, fine grained material. The absence of it about Kilauea, Puu o Keokeo, and on the north slope of Mauna Loa is occasioned by its removal by the later historic discharges of lava. It would not be found near the central vent because the heated air would carry the particles many thousand feet in the air, whence they would descend miles away from their place of origin. The fact that the Mohokea caldera is covered by the ashes is evidence that they came from a distant vent. Had the eruption been in the midst of the depression, we should look for them in an encircling belt, if not upon the southwest side almost exclusively, where they were deflected by the trade winds.

\section{Order of Events in the History of Mohokea}

Several events can be clearly discriminated in the history of the Mohokea caldera.

1. The formation of the cone of Mauna Loa. This is really composite, but may be treated as a unity for convenience. Basalt came from below and flowed over the edge of the primeval crater till the whole dome, 75 by 53 miles in the two diameters and 13,650 feet altitude, had been formed, composed of millions of layers gradually superimposed upon one another. The altitude must have been even greater, so as to allow for the falling in of the surface to develop the caldera of Mokuaweoweo.

2. After the material ceased to flow over the surface, two styles of eruption commenced or continued to be manifested - those high up, allowing streams of molten lava to flow away quietly, and those starting from comparatively low levels, discharging with violence. The base of the cone was filled by these ruptures of the basaltic sheets and the dis- 
charge of streams of melted lava. The irregularities of the southern edge of the cone from Kilauea to the South cape were produced at this time. Mohokea was the most important of these displays. The three intermontane valleys sank down in the usual style of the breaking of the superior crust from a caldera. Perhaps, because of the great size of the pit, all the fragments could not be absorbed by the inner fiery fluid; two rows of blocks were crowded up, and the work of fracture ceasing, the great masses of rock were elevated and held in position. It is to be noted that the faults are at right angles to those running seaward from the apex of Mauna Loa. This agrees with the theory of W. L. Green, that the discharges of the lava from the interior of the cone always take place at the intersection of the cross-fissures. Very much lava flowed away at this time, including the three valleys mentioned and the crust adjacent as far as to Kapuna.

3. Two great eruptions, separated by a long interval of time, threw out into the atmosphere enormous clouds of ashes. The intermediate period was long enough to allow of the invasion of plants over the sterile area of silt. Because of the occurrence of this ash entirely around the circumference of Mauna Loa, it seems most likely that the vent was at Mokuaweoweo. A gigantic cloud of steam carrying dust ascended miles into the air; the cloud rose above the trade winds and spread out on all sides, while the particles too heavy to be carried great distances fell to the ground. Three recent eruptions of a similar nature are on recordfrom Krakatoa in 1883, from Tarawera in 1886, and during the present year at Vesurius. I have estimated that 2,000 square miles of the island of Hawaii were covered by these ashes. These are preserved, but they must have been strewn much beyond these limits and lost in the sea. Could any one have observed the skies at this time he would have seen repeated the sky glows, the Bishops rings, and the green sun. This must have been an explosive eruption-a style of discharge denied to Hawaiian volcanoes by the early writers.

4. Several flows of Pahoehoe will be described presently overlying the ash, some of them from the Mohokea depression itself.

5. More or less connected with them are several discharges of aa.

6. Last of all, I should not fail to recall the disastrous earthquakes of 1868, whose epicentrum lay in the vicinity of this caldera. No more severe shocks have ever been experienced since the country has been settled by people of European descent. The quakes were observed at Kona, Kahuka, Waiohinu, Kau, Kilauea, and Hilo. All were severe, but the greatest devastation was wrought in the vicinity of Mohokea. Can it be that the seat of the seismic disturbances lay beneath Mohokea? The 
chief discharge of lava was on the flank of Mauna Loa several miles west of Mohokea, and there was another from Kilauea in the opposite direction.

\section{Erdptions of Lata from the Lower Levels}

The Mauna Loa flows may be classified by the altitudes at which the discharges take place. First, those from the upper part of the dome, as those of $1843,1852,1855,1859,1880,1889$, and 1899, starting from 9,000 to 11,000 feet above the sea. They are strongly characterized by a hydrostatic connection with the central pit at Mokuaweoweo. The lava comes from the extreme depth under the ocean to the caldera, and after two or three days' stay at the summit it breaks out quietly on the side of the mountain, and may flow to the sealevel in the course of several months. The other class, as represented by the flows of 1868 and 1887 , shows first the same supply of lava at the summit, but breaks out low down, 3,000 or 6,000 feet above the sea, with violent earthquakes, those lowest down being the most frightful, and the lava issues tumultuously through long fissures. I can now add quite a number to the list of those that have issued from the lower level. They were prehistoric, so that it is impossible to connect them with manifestations in Mokuaweoweo.

In this class I will include several undefined aa eruptions east of Pahala. The first poses on the government map as having been erupted in 1823, and is quite near Kilauea. As there represented, I think it is made up of three eruptions. The first, prehistoric, 9,300 feet above the sea, near Puu ula ula, well shown on E. D. Baldwin's unpublished survey. This probably was of the first class, originating high up. The second part must have been of the kind originating low down, starting near the line between the Mauna Loa and Kilauea areas, at an elevation of more than 3,000 feet. A macadamized road now crosses it diagonally for as much as 6 miles, and it is certainly of prehistoric age. It has moved southwest with very little fall. The third part originated from Kilauea in 1823 , and is probably the only area that came to the surface at that time. It was visited by Reverend $\mathrm{Mr}$ Ellis in 1823 and is described in his journal.*

The second mention is that of one or more ancient flows between the Halfway House and Pahala. Some of them cover the yellow ash beds, others are much older, or at least they had their day before the deposit

* I have been unable to discover from whence the compilers of the map could have derived the theory of the connection between the upper eruption of Mauna Loa and that from Kilauea in 1823. None of the Survey officers, past or present, can state whence the information was obtained. 
of ash. Some of the recent exposures show a beautifully smooth pahoehoe, which when protected by an earthy covering really recall, by their freshness and smoothness, glaciated surfaces in more northern climes. Mr Mann, one of the lunas at Hilea, told me he had seen five different lava flows belonging to this later period to the east of Pahala. They have a thickness of 28 feet. This is in the vicinity of the mud flow of 1868 .

Thirdly, extensive aa flows, which have originated in the depressed area of Mohokea east of Pun Enuhe.

The fourth eruption is aa from between Puu Enuhe and Makawao.

The fifth eruption is made up of at least three aa flows and the later pahoehoe between Hilea and Hanuapo.

In the sixth area there are some undetermined factors. Undoubtedly there were discharges on the Kahuku promontory between Honuapo and the 1868 flow, but we are sure of those of 1868 and $188 \%$, which have been fully described. Farther north I observed from the steamer half a dozen of these short flows, of very modern aspect, before reaching Cape Honumalo. Here commences the steeper slopes of the Kona district for a distance of 60 miles. Much of the way the 1,000-foot contour is only a mile back from the shore, and it rises nearly as rapidly to 3,000 and 4,000 feet. I observed fresh black lava flows at Hoopaloa, Naupoopoo, and Kailua. It was dark as I sailed from Hoopaloa to Naupoopoo, so it was not possible to say what number of flows might exist between those two localities. Most of this bluff belonged to the sheets originating from Mauna Loa.

\section{HualaLei}

After reaching the Hualalei district the land slopes more gradually to the sea, and the finest of all our illustrations of the low level eruptions is the only eruption from Hualalei of which we have an historic record. It started from the level of 1,800 feet and flowed to the sea in 1801, spreading out very much laterally. 'The distance between the extreme points on the shore exceeds the length of the flow. Three other very distinct earlier but prehistoric flows are delineated on the north side of Hualalei, starting from points 3,700 to 6,000 feet above the sealevel. As Hualalei reaches only to 8,269 feet, at least the highest of these flows may belong to the other variety of discharges.

Hualalei was visited by Menzies, the botanist, in 1794, as stated in the narrative of the voyage of Vancouver. The same gentleman made the attempt to climb Mauna Loa, but for some unknown reason the historian has not had this later report of Menzies printed. There is an excellent 
sketch of the summit crater of Hualalei, with a brief description of the ascent, in the Vancouver narrative. It seems clear, therefore, that there have been many eruptions from the lower levels of the Mauna Loa dome on the south and southwest sides. Whether any or all of them had direct connection with Mokuaweoweo, like those of 1868 and 1887, can not be known, but the description of Mohokea sustains the early formed impression, that it represents an independent caldera. 
